\title{
Synthesis and Characterisation of Nonclassical Ruthenium Hydride Complexes Containing Chelating Bidentate and Tridentate Phosphine Ligands
}

\author{
Martin H. G. Prechtl, ${ }^{[a, b]}$ Yehoshoa Ben-David, ${ }^{[c]}$ Daniela Giunta, ${ }^{[a, b]}$ Stefan Busch, ${ }^{[b]}$ \\ Yuki Taniguchi, ${ }^{[b]}$ Wolfgang Wisniewski, ${ }^{[b]}$ Helmar Görls, ${ }^{[\mathrm{d}]}$ Richard J. Mynott, ${ }^{[\mathrm{b}]}$ \\ Nils Theyssen, ${ }^{[b]}$ David Milstein, ${ }^{[c]}$ and Walter Leitner*[a, $\left.b\right]$
}

\begin{abstract}
The synthesis and characterisation of nonclassical ruthenium hydride complexes containing bidentate PP and tridentate PCP and PNP pincer-type ligands are described. The mononuclear and dinuclear ruthenium complexes presented have been synthesised in moderate to high yields by the direct hydrogenation route (one-
\end{abstract}

pot synthesis) or in a two-step procedure. In both cases $[\mathrm{Ru}(\mathrm{cod})$ $\left.(\text { metallyl })_{2}\right]$ served as a readily available precursor. The influences of the

Keywords: chelates • dihydrogen complexes $\cdot$ hydrides $\cdot$ phosphine ligands $\cdot$ ruthenium coordination geometry and the ligand framework on the structure, binding, and chemical properties of the $\mathrm{M}-\mathrm{H}_{2}$ fragments were studied by X-ray crystal structure analysis, spectroscopic methods, and reactivity towards $\mathrm{N}_{2}, \mathrm{D}_{2}$, and deuterated solvents.

\section{Introduction}

The discovery of stable transition-metal complexes with molecular dihydrogen as a side-on bound ligand by Kubas et al. in 1983 was a breakthrough in the historical development of coordination chemistry. ${ }^{[1]}$ Since then, dihydrogen complexes

[a] Dipl.-Chem. M. H. G. Prechtl, Dr. D. Giunta, Prof. Dr. W. Leitner Institute of Technical and Macromolecular Chemistry RWTH Aachen University

Worringer Weg 1, 52074 Aachen (Germany)

Fax: (+49)241-802-2177

E-mail: leitner@itmc.rwth-aachen.de

[b] Dipl.-Chem. M. H. G. Prechtl, Dr. D. Giunta, Dr. S. Busch, Dr. Y. Taniguchi, W. Wisniewski, Dr. R. J. Mynott, Dr. N. Theyssen, Prof. Dr. W. Leitner

Max-Planck-Institut für Kohlenforschung

Kaiser-Wilhelm-Platz 1

45470 Mülheim/Ruhr (Germany)

[c] Y. Ben-David, Prof. Dr. D. Milstein

Department of Organic Chemistry

Weizmann Institute of Science

76100 Rehovot (Israel)

[d] Dr. H. Görls

Institut für Anorganische und Analytische Chemie Friedrich-Schiller-Universität Jena Carl-Zeiss Promenade 10, 07745 Jena (Germany)

Supporting information for this article is available on the WWW under http://www.chemeurj.org/ or from the author. of transition metals have been the subject of considerable interest because they present models for the metal-induced activation of the hydrogen molecule, ${ }^{[2-4]}$ either through oxidative addition or heterolytic cleavage..$^{[2,3,5-8]}$ In general, it is possible to obtain nonclassical metal-hydride complexes by direct reaction with hydrogen, by protonation of hydride complexes, or by reduction reactions. ${ }^{[3 b]}$ Stable coordination between the molecular dihydrogen and a metal centre is based on two contributions: the donation from the filled $\mathrm{H}_{2}$ $\sigma$ orbital to the empty d orbitals on the metal, and the backbonding of the $\mathrm{d}$ electrons to the antibonding $\sigma^{*}$ orbital of the hydrogen ligand. Thus, several factors, such as the ability of the metal to donate electrons and the nature of the ligand in the trans position, influence the stability and the reactivity of the $\mathrm{M}-\mathrm{H}_{2}$ unit. ${ }^{[3,4,9]}$ As recently highlighted by van Leeuwen et al., the structural demands of an ancillary chelating ligand can also play an important role in defining the properties of $\eta^{2}-\mathrm{H}_{2}$ ligand. ${ }^{[10]}$ In the present paper, we report on the synthesis and characterisation of new nonclassical ruthenium hydride complexes with constrained ligand geometries, which substantiate the importance of well-defined structural features for the $\mathrm{H}_{2}$-binding mode and reactivity. ${ }^{[11]}$

The chemistry of ruthenium complexes containing nonclassical hydride ligands was pioneered by Chaudret et al. with the synthesis of the hexahydride complex of formula 
$\left[\mathrm{Ru}\left(\mathrm{H}_{2}\right)_{2}(\mathrm{H})_{2}\left(\mathrm{PCy}_{3}\right)_{2}\right](\mathbf{1})(\mathrm{Cy}=$ cyclohexyl, Figure 1$) \cdot{ }^{[12]}$ This species was proven to possess a unique structure with two classical hydrides and two molecular dihydrogen ligands in mutually cis positions, ${ }^{[12 c]}$ as confirmed most recently by neutron diffraction for $\left[\mathrm{Ru}\left(\mathrm{H}_{2}\right)_{2}(\mathrm{H})_{2}\left(\mathrm{PCyp}_{3}\right)_{2}\right](\mathrm{Cyp}=\mathrm{cy}-$ clopentyl). ${ }^{[12 \mathrm{~d}]}$ Meanwhile, several ruthenium complexes containing nonclassical hydride ligands have been synthesised, allowing a better understanding of the stability, reactivity, and binding mode of the $\eta^{2}-\mathrm{H}_{2}$ moiety. ${ }^{[13,14]}$ Complex $\mathbf{1}$ has found application as a starting material for a variety of ruthenium-dihydrogen complexes. ${ }^{[13-15]}$ Moreover, it has been used as a catalyst precursor for hydrogenation, ${ }^{[13,16]}$ silylation, ${ }^{[17]}$ coupling reactions (Murai reaction), ${ }^{[15,18]}$ and metathesis. ${ }^{[19]}$

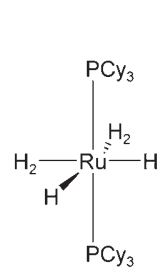

1

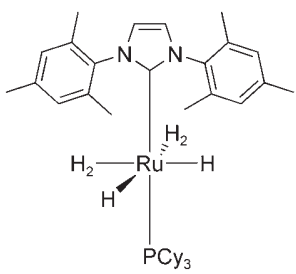

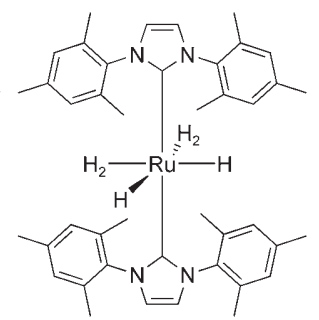

Figure 1. $\left[\mathrm{Ru}\left(\mathrm{H}_{2}\right)_{2}(\mathrm{H})_{2}\left(\mathrm{PCy}_{3}\right)_{2}\right] \quad(\mathbf{1}), \quad\left[\mathrm{Ru}\left(\mathrm{H}_{2}\right)_{2}(\mathrm{H})_{2}\left(\mathrm{PCy}_{3}\right)(\mathrm{IMes})\right]$ $\left[\mathrm{Ru}\left(\mathrm{H}_{2}\right)_{2}(\mathrm{H})_{2}(\mathrm{IMes})_{2}\right](\mathbf{3})$.

Recently, we reported the synthesis of new complexes 2 and $\mathbf{3}$, in which one or both $\mathrm{PCy}_{3}$ ligands of $\mathbf{1}$ are replaced with strongly basic and sterically encumbered heterocyclic carbene ligands. ${ }^{[20]} \mathrm{X}$-ray crystal structure analysis revealed that the arrangement of the central $\mathrm{RuH}_{6}$ core is largely retained in these species. However, as a result of the specific ligand environment, the reactivity of the carbene differs from that of $\mathbf{1}$, including an interesting potential use in catalytic H/D exchange processes. ${ }^{[20,21]}$ An alternative possibility for expansion of the structural variety of nonclassical ruthenium-hydride complexes is to incorporate the donor sites into chelating frameworks with constrained geometries. ${ }^{[10]}$ In the present work, we have therefore set out to investigate more systematically bi- and tridentate chelating ligand frameworks for the stabilisation of bi- and mononuclear ruthenium dihydrogen complexes (Figure 2).

Preliminary studies from our team ${ }^{[1]}$ and in industrial laboratories ${ }^{[16]}$ indicate that binuclear complexes of the general formula $\left[\mathrm{Ru}_{2} \mathrm{H}_{6}\left(\mathrm{P}_{2}\right)_{2}\right]$ can be obtained with chelating ligands $\mathrm{P}_{2}$ of type $\mathrm{R}_{2} \mathrm{P}\left(\mathrm{CH}_{2}\right)_{n} \mathrm{PR}_{2}$. Herein, we describe the synthesis of ruthenium complexes $\left[\mathrm{H}\left(\mathrm{P}_{2}\right) \mathrm{Ru}(\mu-\mathrm{H})_{3} \mathrm{Ru}\left(\mathrm{P}_{2}\right)\left(\mathrm{H}_{2}\right)\right](\mathbf{4} \mathbf{a}$ : $\mathrm{P}_{2}=\mathrm{Cy}_{2} \mathrm{P}\left(\mathrm{CH}_{2}\right)_{3} \mathrm{PCy}_{2}$ dcpp; 4b: $\mathrm{P}_{2}=\mathrm{Cy}_{2} \mathrm{P}\left(\mathrm{CH}_{2}\right)_{2} \mathrm{PCy}_{2}$ dcpe) and the complete spectroscopic and crystallographic characterisation of $\mathbf{4 a}$. The ligands were chosen to largely retain the electronic nature of the ligands in $\mathbf{1}$ while enforcing a cis geometry with a defined P-M-P angle to allow systematic comparison with similar dinuclear ruthenium complexes previously reported in the literature. To obtain mononuclear structures we have applied PCP and PNP pincer li-
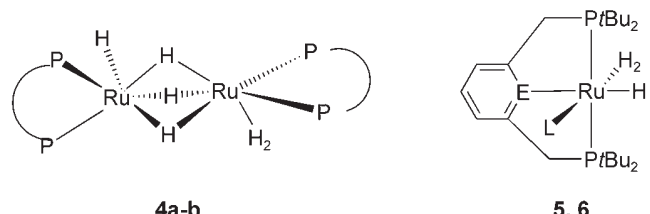

Figure 2. Binuclear complexes $\mathbf{4}$ and pincer-typed mononuclear complexes 5 and 6. $\mathrm{P} \cap \mathrm{P}=\mathrm{Cy}_{2} \mathrm{P}-\left(\mathrm{CH}_{2}\right)_{n}-\mathrm{PCy} ; \mathbf{4 a}\left[\mathrm{Ru}_{2} \mathrm{H}(\mu-\mathrm{H})_{3}\left(\mathrm{H}_{2}\right)(\mathrm{dcpp})_{2}\right]$, $n=3,\left(\mathrm{dcpp}=1,3\right.$-bis(dicyclohexylphosphino)propane); $\mathbf{4 b}\left[\mathrm{Ru}_{2} \mathrm{H}(\mu\right.$ $\left.\mathrm{H})_{3}\left(\mathrm{H}_{2}\right)(\text { dcpe })_{2}\right], n=2$, (dcpe $=1$,2-bis(dicyclohexylphosphino)ethane); $5\left(\mathrm{E}=\mathrm{C} ; \mathrm{L}=\mathrm{H}_{2}\right)$ : $\left[\mathrm{Ru}(\mathrm{dtbpmb})\left(\mathrm{H}_{2}\right)_{2} \mathrm{H}\right],(\mathrm{dtbpmb}=1,3$-bis(di-tert-butylphosphinomethyl)benzol); $6(\mathrm{E}=\mathrm{N} ; \mathrm{L}=\mathrm{H})$ : [Ru(dtbpmp) $\left.\mathrm{H}_{2}\left(\mathrm{H}_{2}\right)\right]$, (dtbpmp $=1,3$-bis(di-tert-butylphosphinomethyl)pyridine).

gands in complexes $\mathbf{5}$ and $\mathbf{6}$, respectively, to force a meridional tridentate coordination mode. Owing to their interesting catalytic behaviour, transition-metal complexes containing tridentate pincer ligands have been studied extensively during the past decade. ${ }^{[22]}$ However, there are limited examples of ruthenium-centred complexes, and no ruthenium dihydrogen complexes with such ligands have been reported so far. In contrast, a number of rhodium, platinum, and osmium complexes containing these pincer ligands are known. ${ }^{[22,23]}$ Recently, a ruthenium dihydrogen complex bearing an aliphatic POP pincer was presented. ${ }^{[23 \mathrm{f}]}$

\section{Results and Discussion}

Complexes $4 \mathbf{a}$ and $\mathbf{4 b}$ are readily obtained by hydrogenation of the allyl complexes $7 \mathbf{a}$ and $\mathbf{7 b}$ following a procedure previously developed in our group (Scheme 1). ${ }^{[11,24]}$ Under

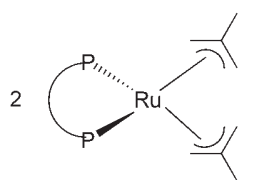

$7 a, b$

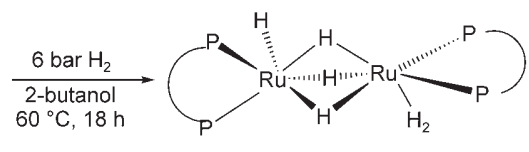

$4 a, b$
Scheme 1. Formation of complexes of type $\mathbf{4 a}(100 \%)$ and $\mathbf{4 b}(36 \%)$ by hydrogenation of allyl-type complexes 7a $\left(\mathrm{P}_{2}=\mathrm{dcpp}\right)$ and $\mathbf{7 b}\left(\mathrm{P}_{2}=\right.$ dcpe).

optimised conditions, $\mathbf{4 a}$ and $\mathbf{4 b}$ have been isolated in fair to excellent yields as orange microcrystalline solids directly from the reaction mixture upon cooling and filtration. Complex 4 a shows high solubility in aromatic solvents and is remarkably stable in the solid state, even in the presence of air or under vacuum. Although the compounds are too thermally labile to detect the molecular ions directly, the fragmentation observed in mass spectroscopic analysis confirms a dinuclear structure for complex $4 \mathbf{a}$.

The IR spectra of complexes $\mathbf{4 a}$ and $\mathbf{4 b}$ show characteristic bands that are readily assigned to terminal hydrides $(\mathrm{Ru}-\mathrm{H})$ and bridging hydrides $(\mathrm{Ru}-\mathrm{H}-\mathrm{Ru})$, located for $\mathbf{4 a}$ at $\tilde{v} 1990$ and $1552 \mathrm{~cm}^{-1}$, respectively. As other parts of the IR 
spectrum of $\mathbf{4 a}$ are dominated by the bands resulting from the dcpp ligands, the IR spectrum of the corresponding deuterated complex $\left[\mathrm{D}_{6}\right]-\mathbf{4 a}$ a was also examined. The two bands for the terminal and bridging hydrides show an isotope shift of $\sqrt{ } 2$ in accordance with the Teller-Redlich rule. ${ }^{[25]}$ In addition, a new band appears at $1719 \mathrm{~cm}^{-1}$ in the spectrum of $\left[\mathrm{D}_{6}\right]-\mathbf{4 a}$, which can be assigned to the $\mathrm{D}-\mathrm{D}$ stretching of a coordinated $\mathrm{D}_{2}$ molecule. Even if $v_{\mathrm{H}-\mathrm{H}}$ cannot be determined exactly by the Teller-Redlich rule, which is valid for uncoupled oscillations only, this result indicates the presence of a $\sigma$-coordinated dihydrogen molecule in $\mathbf{4 a}$.

The ${ }^{1} \mathrm{H}$ NMR spectrum of $\mathbf{4 a}$ shows a single averaged signal for all hydridic ligands as a slightly broad singlet centred at $\delta=-11.8 \mathrm{ppm}$, which integrates for six $\mathrm{H}$ atoms at various relaxation delays. The chemical shift value has also been confirmed by ${ }^{2} \mathrm{H}$ NMR experiments with $\left[\mathrm{D}_{6}\right]-\mathbf{4 a}$. When $\left[\mathrm{D}_{6}\right]-\mathbf{4}$ a was generated in situ by charging a solution of $4 \mathbf{a}$ in $\left[D_{8}\right]$ toluene with $D_{2}$ gas in a Young NMR tube, the deuterium spectrum also revealed several signals between $\delta$ $=1.1$ and $1.9 \mathrm{ppm}$. These signals indicate $\mathrm{H} / \mathrm{D}$ exchange by a $\mathrm{C}-\mathrm{H}$ activation process at various positions of the dcpp ligands. The ${ }^{31} \mathrm{P}$ NMR signal of $\mathbf{4} \mathbf{a}$, which at room temperature is detected at $\delta=69.5 \mathrm{ppm}$, splits into two broad signals when the temperature is lowered to $-80^{\circ} \mathrm{C}$. The highfield proton signal does not yet show significant decoalescence at this temperature. Owing to the fast exchange between classical and nonclassical hydrides even at low temperature, it was not possible to determine separate resonance frequencies for the individual hydridic ligands or to measure $\mathrm{P}-\mathrm{H}$ coupling constants.

In order to further evaluate the nature of the hydridic ligands in complex $\mathbf{4 a}$, the minimum relaxation time $T_{1}(\mathrm{~min})$ was determined. ${ }^{[26]}$ The values measured with a $400 \mathrm{MHz}$ NMR spectrometer at various temperatures are graphically displayed in Figure 3. The $T_{1}(\mathrm{~min})$ for $\mathbf{4 a}$ was determined as $53 \mathrm{~ms}$ at $271 \mathrm{~K}$. A comparison with the values reported for other similar complexes confirms the presence of a nonclassical structure, which is usually associated with $T_{1}(\min )<$ $100 \mathrm{~ms}$. An $\mathrm{H}-\mathrm{H}$ distance of $104 \mathrm{pm}( \pm 1 \mathrm{pm}$ based on instrumental errors) can be calculated from the $T_{1}(\mathrm{~min})$ measurement. Owing to dynamic exchange with the other hydride signals, this value can be regarded only as the upper limit for the distance in the coordinated $\mathrm{H}_{2}$ moiety, however.

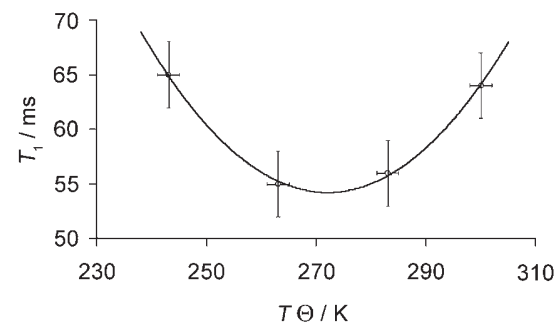

Figure 3. Temperature-dependent evolution of the $T_{1}$ values measured for 4 a. $T_{1} / \mathrm{ms}(\Delta 3 \mathrm{~ms})$ [ $T / \mathrm{K}(\Delta 2 \mathrm{~K})$ ]: 64 [300], 56 [283], 55 [263], 65 [243], 108 [223].
Additional evidence for the presence of a $\sigma$-coordinated hydrogen molecule is provided by the reaction of complex 4a with molecular nitrogen to form the complex [H$\left.(\mathrm{dcpp}) \mathrm{Ru}(\mu-\mathrm{H})_{3} \mathrm{Ru}(\mathrm{dcpp})\left(\mathrm{N}_{2}\right)\right](\mathbf{8}) \cdot{ }^{[1,3,4]}$ After exposure of a $\left[\mathrm{D}_{8}\right]$ toluene solution of $\mathbf{4 a}$ to a nitrogen stream in a Young valve NMR tube, the high-field region of the ${ }^{1} \mathrm{H}$ NMR spectrum shows, together with a small signal for the starting complex, one apparent doublet at $\delta=-9.2 \mathrm{ppm}(\Delta v=$ $53 \mathrm{~Hz}$ ), one broad signal at $\delta=-15.5 \mathrm{ppm}$ and one triplet at $\delta=-19.4 \mathrm{ppm}\left(\mathrm{t},{ }^{2} J(\mathrm{H}, \mathrm{P})=33 \mathrm{~Hz}\right)$. The ${ }^{31} \mathrm{P}$ NMR shows two signals of equal intensity at $\delta=75.1 \mathrm{ppm}$ (s) and $\delta=47.1 \mathrm{ppm}$ (s) and reveals $9 \%$ of the starting material at $\delta=68 \mathrm{ppm}$ (s). The reaction is reversible and compound $4 \mathbf{a}$ is quantitatively restored when the same solution is exposed to hydrogen gas. Interestingly, $\mathbf{4 a}$ can also easily be converted to $\mathbf{8}$ in the solid state under 14 bar nitrogen pressure, indicating that the coordination sphere in both solution and solid state is identical.

The solid-state structure of the ruthenium hydride $\mathbf{4 a}$ was determined by single-crystal X-ray structure analysis. Crystals of $\mathbf{4 a}$, suitable for X-ray investigation, were obtained by slow evaporation of a hexane solution under hydrogen atmosphere. Figure 4 depicts a graphical representation of the molecular structure and Table 1 summarises selected bond lengths and angles. ${ }^{[27]}$ Notably, all hydrogen atoms in the coordination sphere of the ruthenium centres could be located and fully refined.

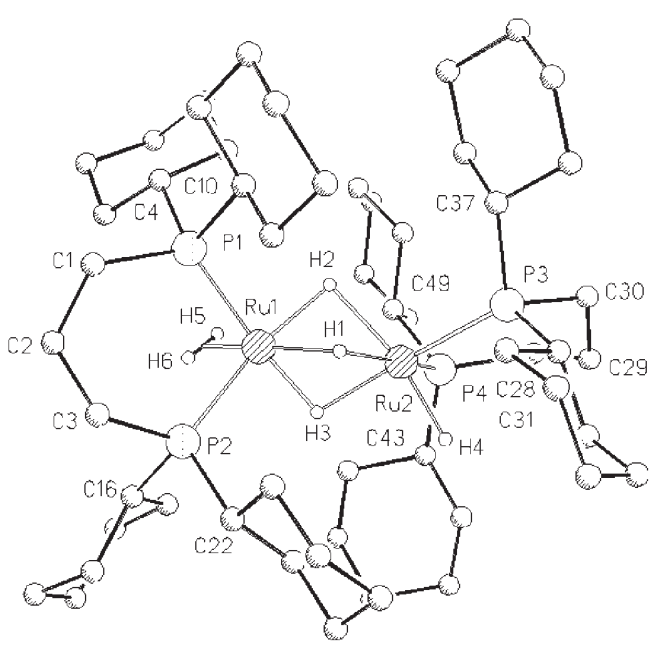

Figure 4. ORTEP diagram of the molecular structure of $\mathbf{4 a}$ as determined by single X-ray diffraction.

The dimeric structure of $\mathbf{4 a}$ is made of two slightly distorted octahedra, whose centres are occupied by the two ruthenium atoms. The phosphine groups exhibit an anticline arrangement, which minimises the steric effect of the cyclohexyl groups in the backbones. The bite angle measured for the two dcpp ligands in $\mathbf{4 a}\left(\approx 95^{\circ}\right)$ is slightly larger than previously reported for $7 \mathbf{a}\left(\approx 91.3^{\circ}\right)$. $^{[2]}$ The distances between the bridging hydrides and the ruthenium centres are significantly longer than those measured for the remaining hydro- 
Table 1. Selected distances and angles of complex $4 \mathbf{a}$

\begin{tabular}{|c|c|c|c|c|c|}
\hline \multicolumn{2}{|c|}{ Distances [Å] } & \multicolumn{4}{|c|}{ Angles $\left[^{\circ}\right]$} \\
\hline Ru1-H1 & $1.83(4)$ & H1-Ru1-H2 & $71.4(15)$ & H6-Ru1-H1 & $70(2)$ \\
\hline $\mathrm{Ru} 1-\mathrm{H} 2$ & $1.78(3)$ & H2-Ru1-H3 & $82.8(14)$ & H3-Ru1-H1 & 76.7 (16) \\
\hline $\mathrm{Ru} 1-\mathrm{H} 3$ & $1.73(3)$ & H5-Ru1-H3 & $157(2)$ & H5-Ru1-H2 & $87.8(18)$ \\
\hline Ru1-H5 & $1.68(4)$ & H5-Ru1-H3 & $91.3(18)$ & H6-Ru1-H2 & $117(2)$ \\
\hline Ru1-H6 & $1.63(6)$ & H6-Ru1-H3 & $98(2)$ & P1-Ru1-P2 & $95.32(3)$ \\
\hline $\mathrm{Ru} 2-\mathrm{H} 1$ & $1.84(4)$ & P1-Ru1-Ru2 & $129.8(18)$ & P2-Ru1-Ru2 & $121.91(2)$ \\
\hline $\mathrm{Ru} 2-\mathrm{H} 2$ & $1.91(3)$ & & & & \\
\hline $\mathrm{Ru} 2-\mathrm{H} 3$ & $1.81(3)$ & H1-Ru2-H2 & $68.4(15)$ & H2-Ru2-H3 & 77.2 (13) \\
\hline $\mathrm{Ru} 2-\mathrm{H} 4$ & $1.61(3)$ & H3-Ru2-H1 & 74.5 (16) & H4-Ru2-H1 & $102.3(17)$ \\
\hline H5-H6 & 0.833 & H4-Ru2-H2 & $166.4(14)$ & H4-Ru2-H3 & 90.9 (15) \\
\hline $\mathrm{Ru} 1-\mathrm{P} 1$ & $2.272(7)$ & P3-Ru2-P4 & $95.91(3)$ & P3-Ru2-Ru1 & $134.73(2)$ \\
\hline $\mathrm{Ru} 1-\mathrm{P} 2$ & $2.274(7)$ & P4-Ru2-Ru1 & $118.21(2)$ & & \\
\hline $\mathrm{Ru} 2-\mathrm{P} 3$ & $2.266(7)$ & & & & \\
\hline \multirow[t]{2}{*}{$\mathrm{Ru} 2-\mathrm{P} 4$} & $2.254(7)$ & Ru1-H1-Ru2 & 88.8 & & \\
\hline & & $\mathrm{Ru} 1-\mathrm{H} 2-\mathrm{Ru} 2$ & 88.0 & & \\
\hline Ru1-Ru2 & $2.569(7)$ & Ru1-H3-Ru2 & 93.3 & & \\
\hline
\end{tabular}

gen atoms. Most significantly, two hydrogen atoms were located in an arrangement characteristic of a coordinated $\mathrm{H}_{2}$ molecule at $\mathrm{Ru} 1$ with an $\mathrm{H}-\mathrm{H}$ distance of $0.83 \AA$. Considering the dynamic behaviour of $\mathbf{4 a}$ in solution, this value is in full agreement with the upper limit derived from $T_{1}$ measurements. The $\mathrm{H}_{2}$ moiety is almost fully aligned with the plane described by the phosphorus atom $\mathrm{P} 2$, the ruthenium centre Ru1, and the bridging hydride $\mathrm{H} 2$. This arrangement may be explained in terms of a favourable overlap between the $\sigma^{*}$ on $\mathrm{H}_{2}$ and a filled $\mathrm{d}$ orbital on the metal, which allows most efficient backbonding.

Comparison of the structure of complex $\mathbf{4 a}$ with the known dimeric ruthenium hydride complexes 9 and 10, containing nonchelating phosphine ligands (Figure 5$)^{[28]}$ contributes to a better understanding of how the electronic and structural environment around the metal centre affects the hydrogen coordination. It has been shown that complex $\mathbf{9}$, with its $\mathrm{PPh}_{3}$ ligand, must be formulated as a nonclassical dihydrogen complex, ${ }^{[28 a]}$ whereas complex 10, with the $\mathrm{PiPr}_{3}$, ligand adopts the form of a classical dihydride. ${ }^{[28 \mathrm{~b}]}$ Following classical arguments, this difference arises because the stronger basicity of the $\mathrm{P} \mathrm{Pr}_{3}$ ligand favours back donation into the antibonding orbital of the coordinated $\sigma-\mathrm{H}_{2}$ ligand, which leads finally to rupture of the $\mathrm{H}-\mathrm{H}$ bond. However, based on the basicity of the phosphine ligands, a classical dihydride structure would also be expected for complex $\mathbf{4 a}$

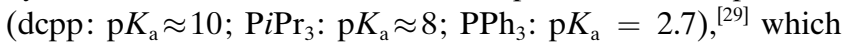
is obviously not in agreement with the experimentally determined structure in the solid state and in solution.
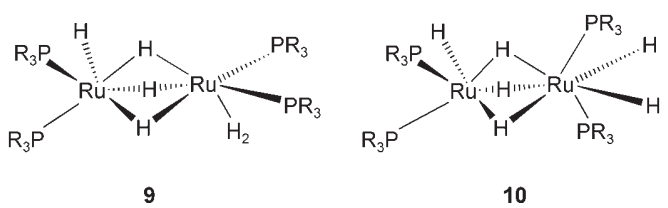

Figure 5. Dinuclear ruthenium hydride complexes $9 \mathbf{a}(\mathrm{R}=\mathrm{Cy}), \mathbf{9 b}(\mathrm{R}=$ $\mathrm{Ph})$, and $10(\mathrm{R}=i \mathrm{Pr})$ containing nonchelating phosphine ligands.
A closer inspection of the molecular structures of the three complexes reveals that the coordination geometry in the P-Ru-P unit plays a more important role in defining the bonding situation of the $\mathrm{Ru}-\mathrm{H}_{2}$ moiety than does the ligands basicity. ${ }^{[10]}$ It is well known that changes in P-M-P coordination geometry can influence the electronic properties at the metal centre more strongly than purely electronic factors through changes in the hybridisation $^{[30 a]}$ or by changing the overlap of the lone pair of the donor with the $\mathrm{M}-\mathrm{P}$ trajectory. ${ }^{[30 b]}$ In the present case, the $-\left(\mathrm{CH}_{2}\right)_{3}$ - backbone in dcpp fixes the two donor units in a cis arrangement with a bite angle of 95.3 (P1-Ru1-P2) and 95.9 (P3-Ru2-P4), very similar to the one observed in $9 \mathbf{b}\left(\approx 95^{\circ}\right)$. The bulky $\mathrm{PiPr}_{3}$ ligands in $\mathbf{1 0}$ maximise their distance freely, thus widening the $\mathrm{P}-\mathrm{Ru}-\mathrm{P}$ angles to 113.10 (P1-Ru1-P2) and $106.75^{\circ}$ (P3-Ru2$\mathrm{P} 4)$. Thus, the nonclassical structure in the dimeric complexes can be associated with the smaller bite angle, whereas the dihydride structure is adopted for larger bite angles. If the angle opens up fully to adjust a trans arrangement of the two donor ligands, the dimeric structures break up to form the monomeric complexes of type 1-3 in the presence of excess hydrogen. Naturally, this is not possible if the cis arrangement is permanently fixed as in the complexes with bidentate ligands.

In an attempt to generate monomeric nonclassical ruthenium hydride complexes with a chelating ligand framework, we turned our attention toward pincer-type ligands that allow a trans arrangement of two electron-rich and bulky phosphorous donor groups. In a one pot procedure, $[\mathrm{Ru}-$ $($ cod $\left.)(\text { metallyl })_{2}\right] \mathbf{1 1}$ was hydrogenated $(7$ bar $)$ at $50{ }^{\circ} \mathrm{C}$ in the presence of phosphine 12. A reddish-brown solid precipitated from $\mathrm{MeOH}$ solution and was isolated by filtration of the reaction mixture at room temperature.

${ }^{1} \mathrm{H}$ NMR and ${ }^{31} \mathrm{P}$ NMR analysis in $\left[\mathrm{D}_{8}\right] \mathrm{THF}$ solution confirmed the presence of the new nonclassical polyhydride complex $\left[\mathrm{Ru}(\mathrm{dtbpmb})\left(\mathrm{H}_{2}\right)_{2} \mathrm{H}\right] \mathbf{5}$ (dtbpmb = 1,3-bis $((\mathrm{di}$-tertbutylphosphino)methyl)benzyl) as major reaction product, together with small amounts $(<10 \%)$ of unidentified side products. In solution the nonclassical trihyride $\mathbf{1 3}$ is generated owing to loss of $\mathrm{H}_{2}(38 \%)$. The two dihydrogen complexes $\mathbf{5}$ and $\mathbf{1 3}$ result from coordination of the ligand and intramolecular $\mathrm{C}-\mathrm{H}$ activation at the 2-position in the aromatic ring (Scheme 2). ${ }^{[11]}$ At room temperature the five hydrogen atoms in the coordination sphere of the ruthenium centre of complex $\mathbf{5}$ give rise to an average broad signal centred at $\delta=-9.21 \mathrm{ppm}$, while the equivalent phosphorous atoms lead to a singlet at $\delta=+107.8 \mathrm{ppm}$ in the ${ }^{31} \mathrm{P}$ NMR spectrum. ${ }^{1} \mathrm{H}$ NMR experiments performed at low tempera- 
ture $\left(-80^{\circ} \mathrm{C}\right)$ allowed identification of the individual signals for the $\mathrm{Ru}-\mathrm{H}\left(\delta=-11.83 \mathrm{ppm}, \mathrm{t},{ }^{2} J(\mathrm{H}, \mathrm{H})=17.7 \mathrm{~Hz}\right)$ and $\mathrm{Ru}-\mathrm{H}_{2}(\delta=-7.01$ and $-5.04 \mathrm{ppm}$, broad signals $)$ moiety. The high-field ${ }^{1} \mathrm{H}$ NMR signals for $\left[\mathrm{Ru}(\mathrm{dtbpmb})\left(\mathrm{H}_{2}\right) \mathrm{H}\right] \mathbf{1 3}$ also reveal $\mathrm{Ru}-\mathrm{H}(\delta=-35.2 \mathrm{ppm})$ and $\mathrm{Ru}-\mathrm{H}_{2}(\delta=$ $-3.67 \mathrm{ppm})$ units. The corresponding ${ }^{31} \mathrm{P}$ resonance is found at $\delta=104.3 \mathrm{ppm}$. The ratio of the nonclassical pentahydride to trihydride complexes was determined to be $\mathbf{5 : 1 3}=$ $58: 42$. The treatment of the NMR sample in $\left[\mathrm{D}_{8}\right] \mathrm{THF}$ with a stream of $\mathrm{H}_{2}$ at room temperature for 10 minutes gives exclusively compound $\mathbf{5}$ from $\mathbf{1 3}$. The reaction of $\mathbf{5}$ with

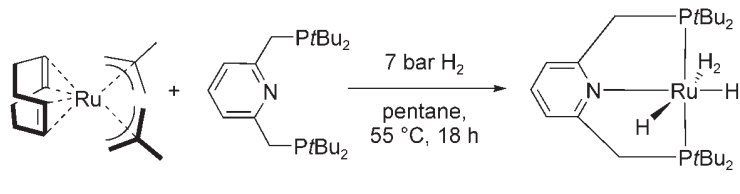

17

Scheme 4. Direct hydrogenation of $\left[\mathrm{Ru}(\mathrm{cod})(\text { metallyl })_{2}\right](\mathbf{1 1})$ in the presence of dtbpmp (17) to give the nonclassical ruthenium hydride complex 6.

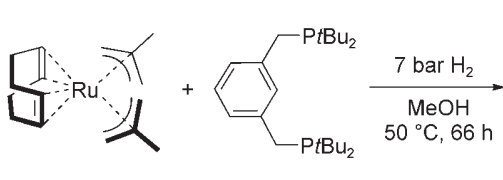

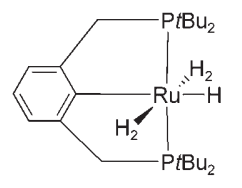

Scheme 2. Formation of 5 by hydrogenation of $\left[\mathrm{Ru}(\mathrm{cod})(\text { metallyl })_{2}\right](\mathbf{1 1})$ in presence of the PCP pincer precursor phosphine 12. The pentahydride $\mathbf{5}$ is the main product formed under hydrogen atmosphere. Trihydride $\mathbf{1 3}$ is generated in solution by $\mathrm{H}_{2}$ loss.

$\mathrm{CD}_{2} \mathrm{Cl}_{2}$ at room temperature gave the known ruthenium complex $[\mathrm{Ru}(\mathrm{dtbpmb}) \mathrm{HCl}] \mathbf{1 6}$ according to ${ }^{1} \mathrm{H}$ and ${ }^{31} \mathrm{P}$ NMR (Scheme 3. ${ }^{[23 a, 31]}$

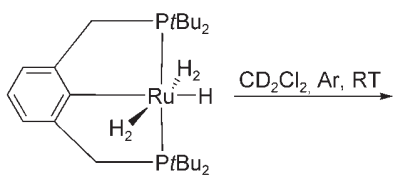

5

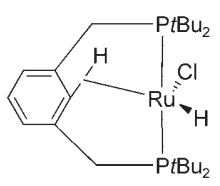

16

Scheme 3. Formation of $[\mathrm{Ru}(\mathrm{dtbpmb}) \mathrm{HCl}] \mathrm{1})$ at room temperature.

$\left[\mathrm{Ru}(\mathrm{cod})(\text { metallyl })_{2}\right] \mathbf{1 1}$ reacts cleanly under similar conditions with the direct hydrogenation route and the PNP pincer ligand dtbpmp $\mathbf{1 7}$ to give the complex [Ru(dtbpmp) $\left.\mathrm{H}_{2}\left(\mathrm{H}_{2}\right)\right] \mathbf{6}$ (Scheme 4). Complex $\mathbf{6}$ is isolated directly from the reaction mixture by filtration at room temperature; it is a light-brown, microcrystalline powder obtained good yields under optimised conditions. In contrast to the situation in complex $\mathbf{5}$, the neutral two-electron donor group of the pyridine moiety in $\mathbf{1 7}$ results in the coordination of two classical hydrides and one molecular hydrogen ligand. At room temperature, the ${ }^{1} \mathrm{H}$ NMR spectrum has a signal at $\delta=-7.3 \mathrm{ppm}\left(\mathrm{t}, 4 \mathrm{H},{ }^{2} J(\mathrm{H}, \mathrm{P})=13.2 \mathrm{~Hz}\right)$ and upon cooling the sample to $-80^{\circ} \mathrm{C}$ the triplet changes to a broad signal. $T_{1}$ (min) was found to be $77 \mathrm{~ms}$ at $\theta_{\min }=228 \mathrm{~K}$ (Figure 6), resulting in an upper limit of $111 \mathrm{pm}$ ( $\pm 1 \mathrm{pm}$, based on instrumental error) for the $\mathrm{H}-\mathrm{H}$ distance in the $\mathrm{H}_{2}$ moiety.

The dihydrogen ligand in complex 6 can be replaced by $\mathrm{N}_{2}$, but the reactivity of $\mathbf{6}$ differs significantly from that of complexes 1-4 (Scheme 5). Firstly, the ligand exchange is

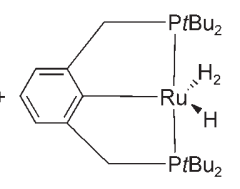

13 relatively slow (66\% conversion after $90 \mathrm{~min}$ ) and small amounts of unreacted $\mathbf{6}$ can be detected by ${ }^{1} \mathrm{H}$ NMR spectroscopy even after bubbling a stream of nitrogen through a solution of $\mathbf{6}$ in $\left[\mathrm{D}_{8}\right]$ toluene overnight. Furthermore, the complex $\left[\mathrm{Ru}(\mathrm{dtbpmp}) \mathrm{H}_{2}\left(\mathrm{~N}_{2}\right)\right]$ 18 (we assume it to be monomeric but a dinitrogen-bridged dimer cannot be excluded of course; ${ }^{31} \mathrm{P}$ NMR: $\delta=$

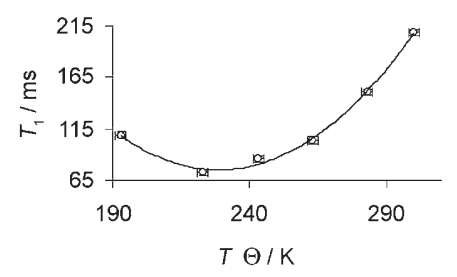

Figure 6. $T_{1}$ values as a function of temperature determined for [Ru(dtbpmp) $\left.\mathrm{H}_{2}\left(\mathrm{H}_{2}\right)\right]$ 6. $T_{1} / \mathrm{ms}(\Delta 3 \mathrm{~ms})[T / \mathrm{K}(\Delta 2 \mathrm{~K})]: 209$ [300], 151 [283], 104 [263], 86 [243], 73 [223], 109 [193].

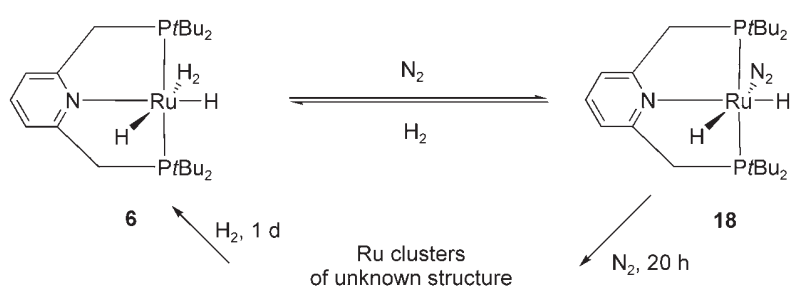

Scheme 5. Reversible formation of dinitrogen complex $\mathbf{1 8}$ and ruthenium clusters from 6 under $\mathrm{N}_{2}$ and $\mathrm{H}_{2}$ atmosphere.

+99.6 ppm; ${ }^{1} \mathrm{H}$ NMR: $\delta=-4.6\left(\mathrm{t},{ }^{2} J(\mathrm{H}, \mathrm{P})=16.81 \mathrm{~Hz}\right)$ and $-12.8 \mathrm{ppm}$ ) appears to be unstable and converts to a dynamic system of presumably polynuclear complexes as indicated by two sets of broad signals at $\delta=+81-74$ and $+70-65$ ppm (see Supporting Information for details). This process is fully reversible and complex $\mathbf{6}$ is restored quantitatively (by NMR) under hydrogen atmosphere.

${ }^{1} \mathrm{H}$ NMR studies of the long term stability of complex 6 in aromatic solvents reveal an interesting H/D exchange pro- 
cess in $\left[\mathrm{D}_{8}\right]$ toluene or $\mathrm{C}_{6} \mathrm{D}_{6}$, whereby complex 6 incorporates deuterium from the solvents into the PNP pincer backbone $\left(\left[D_{x}\right]-6\right.$, Scheme 6). Preferably, the $C 4$ position of the

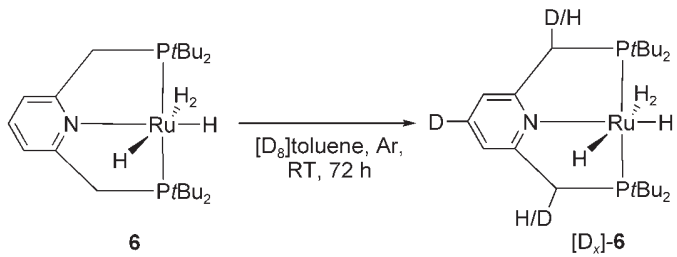

Scheme 6. Formation of $\left[\mathrm{D}_{x}\right]-\mathrm{Ru}(\mathrm{dtbpmp}) \mathrm{H}_{2}\left(\mathrm{H}_{2}\right)\left[\mathrm{D}_{x}\right]-6$ starting from 6 with $\left[\mathrm{D}_{8}\right]$ toluene at room temperature within $72 \mathrm{~h}$.

pyridyl system $(\delta=6.5 \mathrm{ppm} ;>95 \% \mathrm{D})$ and the benzylic positions $(\delta=3.1 \mathrm{ppm} ; \approx 25 \% \mathrm{D})$ are deuterated within $72 \mathrm{~h}$ at room temperature. Interestingly, the hydride area of the ${ }^{1} \mathrm{H}$ NMR still shows hydridic signal at this stage. This indicates that a slow H/D exchange between 6 and the solvent is followed by a rapid exchange at the pincer backbone from the intermediate ruthenium deuteride. After three weeks, the sealed NMR sample also shows a decrease of signal intensity in the tert-butyl resonances and a significant increase of the solvent residue $\mathrm{H}$ signal is also detected. The ${ }^{31} \mathrm{P}$ NMR spectra of this sample still shows mainly the signal of 6 at $\delta=109 \mathrm{ppm}(>90 \%)$, with additional small signals between $\delta=107$ and $88 \mathrm{ppm}$. After 3.5 months the ${ }^{31} \mathrm{P}$ NMR spectrum of the same sample remains identical, but the ${ }^{1} \mathrm{H}$ NMR spectrum shows further decrease of the signal intensity in all molecular parts including the hydride moiety and an increase of the solvent residue signal. In a further experiment we performed the deuteration of 6 in $\mathrm{C}_{6} \mathrm{D}_{6}$ at $50{ }^{\circ} \mathrm{C}$ for $48 \mathrm{~h}$. Analysis by ${ }^{2} \mathrm{H}$ NMR confirmed unequivocally the incorporation of deuterium in the hydride, aliphatic, and aromatic parts, and ${ }^{1} \mathrm{H}$ NMR spectroscopy revealed that $>90 \%$ of the hydrogen atoms in $\mathbf{6}$ are substituted by deuterium in all positions.

Similar results were obtained when the complex synthesis was performed using $\mathrm{D}_{2}$ gas instead of $\mathrm{H}_{2}$. Again the $\mathrm{C} 4$ position $(>95 \%$ D) and the benzylic positions $(\approx 25 \% \mathrm{D})$ were deuterated as indicated by comparison of the IR spectra (Figure 7) and NMR of $\mathbf{6}$ and $\left[\mathrm{D}_{x}\right]-\mathbf{6}$. The IR spectra of

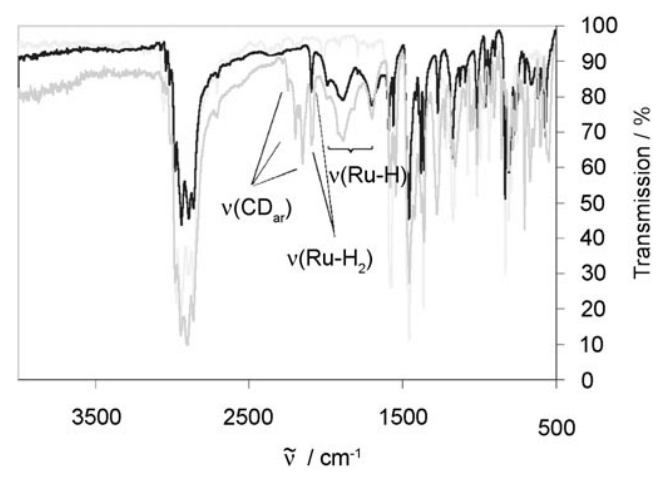

Figure 7. Comparison of the IR spectra of $\left[\mathrm{Ru}(\mathrm{dtbpmp}) \mathrm{H}_{2}\left(\mathrm{H}_{2}\right)\right]$ (6) (black), $\left[\mathrm{D}_{x}\right]-\mathrm{Ru}(\mathrm{dtbpmp}) \mathrm{H}_{2}\left(\mathrm{H}_{2}\right) \quad\left[\mathrm{D}_{x}\right]-6$ (grey) and the free ligand dtbpmp 17 (light grey). the non-deuterated complex 6 show bands characteristic of ruthenium hydrides at 1990, 1892, and $1700 \mathrm{~cm}^{-1}(v(\mathrm{Ru}-\mathrm{H}))$ and at $2095 \mathrm{~cm}^{-1}\left(v\left(\mathrm{Ru}-\mathrm{H}_{2}\right)\right)$. Moreover, the spectra of $\left[\mathrm{D}_{x}\right]-6$ includes further bands at 2247,2199 , and $2151 \mathrm{~cm}^{-1}$ which can be assigned as $v\left(\mathrm{CD}_{\mathrm{ar}}\right)$ bands by comparison with the $v\left(\mathrm{CH}_{\mathrm{ar}}\right)$ bands according to the Teller-Redlich rule. ${ }^{[25]}$ The expected bands between 1488 and $1202 \mathrm{~cm}^{-1}$ for ruthenium deuterides could not be detected in the indicated area. These results show that a synthesis of $\left[\mathrm{D}_{4}\right]-6$ seems impossible because during the synthesis under $D_{2}$ gas rapid H/D scrambling occurs and finally a partly deuterated pincer backbone is obtained and the expected ruthenium deuterides are exchanged to ruthenium hydrides.

\section{Conclusion}

In summary, we have presented the synthesis and characterisation of two types of nonclassical ruthenium hydride complexes containing chelating ligands with defined coordination geometries. The straightforward preparation is achieved by hydrogenation of readily available bis-methallyl complexes. Dimeric complexes of type $\mathbf{4}$ are obtained with bidentate cis chelating phosphine ligands, whereas monomeric complexes 5 and $\mathbf{6}$ can be generated with tridentate PCP and PNP pincer ligands. The presence of coordinated dihydrogen molecules was confirmed by X-ray structure analysis and IR and NMR spectroscopic techniques. The stable coordination of the $\mathrm{H}_{2}$ molecule in the binuclear polyhydride complexes is strongly influenced by the coordination geometry, which appears to play a more decisive role than the basicity of the $\mathrm{P}$ donor groups.

The monomeric complex 6 with a PNP pincer ligand shows an interesting reactivity in particular relating to $\mathrm{C}-\mathrm{H}$ bond activation processes. Whereas it is typically the acidic benzylic position that is activated in other ruthenium complexes of this ligand class, ${ }^{[32]}$ complex $\mathbf{6}$ shows a strong preference for the activation of aromatic $\mathrm{C}-\mathrm{H}$ bonds. The implication of this reactivity for catalysis is currently under investigation in our laboratories and will be reported separately.

\section{Experimental Section}

General: All reactions were performed under $\mathrm{Ar}, \mathrm{H}_{2}, \mathrm{D}_{2}$ or $\mathrm{N}_{2}$ atmospheres using Schlenk or glove-box techniques. Solvents and substrates were purchased from Aldrich, Acros, and Strem and were purified according to standard procedures. ${ }^{[33]}$ The PNP ligand dtbpmp 17 was synthesised according to the procedure by Milstein et al. ${ }^{[23]}$ and Hartwig and Kawatsura. ${ }^{[34]}$ The allyl complexes $7 \mathbf{a}$ and $\mathbf{7 b}$ were prepared according to a previously reported synthesis. ${ }^{[24]}$ The syntheses of the ruthenium hydrides were carried out in a modified thick-walled glass reactor (Büchi Glas Uster Miniclave), comparable with a Fischer-Porter bottle.

SAFETY WARNING: The use of pressurised gases can be hazardous and must only be carried out with suitable equipment and under appropriate safety precautions.

[H(depp)Ru( $\left.\boldsymbol{\mu}-\mathbf{H})_{3} \mathbf{R u}(\mathbf{d c p p})\left(\mathbf{H}_{2}\right)\right] \quad$ (4a): Allyl complex 7a $\quad(259 \mathrm{mg}$, $0.4 \mathrm{mmol})$ and hexane $(5 \mathrm{~mL})$ were introduced in a thick-walled glass reactor, which was subsequently charged with $\mathrm{H}_{2}$ (7 bar). The light grey 
suspension was heated under stirring to $55^{\circ} \mathrm{C}$ for $18 \mathrm{~h}$. After cooling to room temperature, the autoclave was vented and the solution was filtered by cannula. Complex $\mathbf{4 a}$ was obtained as a dark orange powder $(216 \mathrm{mg}$, $0.2 \mathrm{~mol} ;>99 \%$ ) after drying under $\mathrm{H}_{2}$ atmosphere. Suitable crystals for $\mathrm{X}$-ray structure analysis were obtained by slow recrystallisation from the mother liquor. For these data, please see Supporting Information. M.p. $230^{\circ} \mathrm{C}$ (decomp); ${ }^{1} \mathrm{H}$ NMR $\left(300 \mathrm{MHz}, \mathrm{C}_{6} \mathrm{D}_{6}, 25^{\circ} \mathrm{C}\right): \delta=2.4-1.1(\mathrm{~m}$, $106 \mathrm{H} ; \quad$ dcpp $),-11.8 \mathrm{ppm}\left(\mathrm{br}, \quad 6 \mathrm{H}, \quad \mathrm{Ru}-H_{\mathrm{n}}\right) ;{ }^{13} \mathrm{C}$ NMR $(75 \mathrm{MHz}$, $\left[\mathrm{D}_{8}\right]$ toluene, $\left.25^{\circ} \mathrm{C}\right): \delta=39.8(\mathrm{t}, 8 \mathrm{C} ; \mathrm{PCH}$ of $\mathrm{Cy}), 29.3\left(\mathrm{~d}, 16 \mathrm{C} ; o-\mathrm{CH}_{2}\right.$ of $\mathrm{Cy}$ ), 28.0 (t, $16 \mathrm{C} ; m-\mathrm{CH}_{2}$ of $\left.\mathrm{Cy}\right), 27.4\left(\mathrm{~s}, 8 \mathrm{C} ; p-\mathrm{CH}_{2}\right.$ of $\left.\mathrm{Cy}\right), 24.5(\mathrm{~s}$, $2 \mathrm{C} ; \mathrm{PCH}_{2} \mathrm{CH}_{2} \mathrm{CH}_{2} \mathrm{P}$ ), $24.2 \mathrm{ppm}$ (t, $\left.4 \mathrm{C} ;, \mathrm{PCH}_{2} \mathrm{CH}_{2} \mathrm{CH}_{2} \mathrm{P}\right) ;{ }^{31} \mathrm{P} \mathrm{NMR}$ $\left(122 \mathrm{MHz}, \mathrm{C}_{6} \mathrm{D}_{6}, 25^{\circ} \mathrm{C}\right): \delta=69.5 \mathrm{ppm}(\mathrm{s}) ; \mathrm{IR}(\mathrm{KBr}): \tilde{v}=2927\left(\mathrm{~s} ; v_{\mathrm{CH}_{2}}\right)$, 2846 (s; $\left.v_{\mathrm{CH}_{2}}\right), 1990$ (w; Ru-H), 1552 (w; Ru-H-Ru), 1445 (s; $\delta_{\mathrm{CH}_{2}}$ ), $1415 \mathrm{~cm}^{-1}\left(\mathrm{~m} ; \delta_{\mathrm{CH}_{2}}\right)$; elemental analysis calcd $(\%)$ for $\mathrm{C}_{54} \mathrm{H}_{106} \mathrm{P}_{4} \mathrm{Ru}_{2}$ (1081.5): C 59.97, H 9.88, P 11.46, Ru 18.69; found: C 59.67, H 9.74, P 11.50, Ru 18.83

$\left[D(d c p p) R u(\mu-D)_{3} R u(d c p p)\left(D_{2}\right)\right]\left(\left[D_{6}\right]-4 a\right)$ : Prepared as $4 \mathbf{a}$ by the use of deuterium gas. ${ }^{2} \mathrm{H}$ NMR $\left(400 \mathrm{MHz}\right.$, hexane, $\left.25^{\circ} \mathrm{C}\right): \delta=1.48-0.68$ (dcpp), -12.22 ppm (s, 6D; Ru-D); IR (KBr): $\tilde{v}=2924$ (s; $\left.v_{\mathrm{CH}_{2}}\right), 2846$ (s, $\left.v_{\mathrm{CH}_{2}}\right), 2652 \mathrm{w}, 1445\left(\mathrm{~s} ; \delta_{\mathrm{CH}_{2}}\right), 1415 \mathrm{~m}\left(\mathrm{~s} ; \delta_{\mathrm{CH}_{2}}\right)$

\section{Reaction of $\left[H(d c p p) R u(\mu-H)_{3} R u(d c p p)\left(H_{2}\right)\right]$ (4a) with deuterium gas} to $\left[D_{6}\right]-4 a$ : A Young NMR tube containing a $\left[D_{8}\right]$ toluene solution of $\mathbf{4 a}$ was cooled with liquid nitrogen. After evacuation the tube was slowly charged with $\mathrm{D}_{2}\left(0.5\right.$ bar) and warmed up to room temperature. The ${ }^{1} \mathrm{H}$ NMR spectrum was measured over 10 minutes. ${ }^{1} \mathrm{H}$ NMR $(300 \mathrm{MHz}$, $\left[\mathrm{D}_{8}\right]$ toluene, $25^{\circ} \mathrm{C}$ ): $\delta=1.11-2.36 \mathrm{ppm}$ (dcpp), (no hydride signal observed in the hydride region); ${ }^{31} \mathrm{P}$ NMR $\left(122 \mathrm{MHz},\left[\mathrm{D}_{8}\right]\right.$ toluene, $\left.25^{\circ} \mathrm{C}\right): \delta$ $=68.1 \mathrm{ppm}(\mathrm{s})$.

Reaction of $\left[H(d c p p) R u(\mu-H)_{3} \operatorname{Ru}(\operatorname{dcpp})\left(H_{2}\right)\right](4 a)$ with nitrogen gas to 8: A Young NMR tube containing $\left[\mathrm{D}_{8}\right]$ toluene solution of $\mathbf{4 a}$ was slowly charged with $\mathrm{N}_{2}(0.5$ bar $)$ at room temperature. ${ }^{1} \mathrm{H}$ NMR $(300 \mathrm{MHz}$, $\left[\mathrm{D}_{8}\right]$ toluene, $\left.25^{\circ} \mathrm{C}\right): \delta=1.17-3.21$ (br; dcpp), $-9.20\left(\mathrm{~d},{ }^{2} J(\mathrm{H}, \mathrm{P})=\right.$ $53 \mathrm{~Hz} ; \mu-H),-15.50\left(\mathrm{br} ; \mu-H_{0}\right),-19.41 \mathrm{ppm}\left(\mathrm{t},{ }^{2} J(\mathrm{H}, \mathrm{P})=33 \mathrm{~Hz} ; \mathrm{Ru}-\right.$ $\left.H_{\text {term }}\right) ;{ }^{31} \mathrm{P}$ NMR $\left(122 \mathrm{MHz},\left[\mathrm{D}_{8}\right]\right.$ toluene, $\left.25^{\circ} \mathrm{C}\right): \delta=47.3(\mathrm{~s}), 75.0 \mathrm{ppm}$ (s), the spectrum also revealed $9 \%$ starting material at $\delta=68.0 \mathrm{ppm}(\mathrm{s})$. $\left[\mathbf{H}(\mathbf{d c p e}) \mathbf{R u}(\boldsymbol{\mu}-\mathbf{H})_{3} \mathbf{R u}(\mathbf{d c p e})\left(\mathbf{H}_{2}\right)\right]$ (4b): Starting from the allyl precursor 7b the same procedure used for $\mathbf{4 a}$ was followed. Conversion: $36 \%$. ${ }^{1} \mathrm{H}$ NMR $\left(300 \mathrm{MHz}, \mathrm{C}_{6} \mathrm{D}_{6}, 25^{\circ} \mathrm{C}\right): \delta=0.8-2.3$ (dcpe), $-11.3 \mathrm{ppm}(\mathrm{br}, 6 \mathrm{H}$; $\left.\mathrm{Ru}-H_{\mathrm{n}}\right) ;{ }^{31} \mathrm{P}$ NMR $\left(122 \mathrm{MHz}, \mathrm{C}_{6} \mathrm{D}_{6}, 25^{\circ} \mathrm{C}\right): \delta=114.3 \mathrm{ppm} ;(\mathrm{s}) ; \mathrm{IR}$ $(\mathrm{KBr}): \tilde{v}=2043$ (w; Ru-H), $1653 \mathrm{~cm}^{-1}$ (w; Ru-H-Ru).

[Ru(dtbpmb)( $\left.\left.\mathbf{H}_{2}\right)_{2} \mathbf{H}\right]$ (5): A mixture of [Ru(cod)(metallyl) $)_{2}$ (11) $(0.118 \mathrm{~g}, 0.369 \mathrm{mmol})$ and 1,3-bis(di-tert-butylphosphinomethyl)benzene (12) $(0.146 \mathrm{~g}, 0.370 \mathrm{mmol})$ in methanol $(5 \mathrm{~mL})$ was introduced in a thickwalled glass autoclave, which was subsequently charged with $\mathrm{H}_{2}$ (7 bar) and stirred for $66 \mathrm{~h}$ at $50^{\circ} \mathrm{C}$. After cooling to room temperature, the autoclave was vented and the solution was filtered by cannula and washed twice with small amounts of methanol. Complex 5 was obtained as a reddish brown powder $(80 \mathrm{mg}, 43 \%)$ after drying under $\mathrm{H}_{2}$ atmosphere at $50{ }^{\circ} \mathrm{C}$. M.p. $179.2-180.5^{\circ} \mathrm{C} ;{ }^{1} \mathrm{H}$ NMR $\left(300 \mathrm{MHz},\left[\mathrm{D}_{8}\right] \mathrm{THF}, 25^{\circ} \mathrm{C}\right): \delta=$ $6.85\left(\mathrm{~d},{ }^{3} \mathrm{~J}(\mathrm{H}, \mathrm{H})=7.46 \mathrm{~Hz}, 2 \mathrm{H} ; \mathrm{Ar}-\mathrm{H}\right), 6.57\left(\mathrm{t},{ }^{3} \mathrm{~J}(\mathrm{H}, \mathrm{H})=7.46 \mathrm{~Hz}, 1 \mathrm{H}\right.$; Ar-H), 3.33 (virtualt $\left.,{ }^{2} J(\mathrm{H}, \mathrm{P})=4 \mathrm{~Hz}, 4 \mathrm{H} ; \mathrm{CH}_{2}\right), 1.22$ (virtualt, ${ }^{3} J(\mathrm{H}, \mathrm{P})$ $\left.=6.10 \mathrm{~Hz}, 36 \mathrm{H} ; \mathrm{CH}_{3}\right),-9.21 \mathrm{ppm}(\mathrm{br}, 5 \mathrm{H} ; \mathrm{Ru}-\mathrm{H}) ;{ }^{31} \mathrm{P}$ NMR $(122 \mathrm{MHz}$, $\left.\left[\mathrm{D}_{8}\right] \mathrm{THF}, 25^{\circ} \mathrm{C}\right): \delta=107.79 \mathrm{ppm} ;{ }^{1} \mathrm{H}$ NMR $\left(300 \mathrm{MHz},\left[\mathrm{D}_{8}\right] \mathrm{THF}\right.$, $\left.-80^{\circ} \mathrm{C}\right): \delta=6.76\left(\mathrm{~d},{ }^{3} J(\mathrm{H}, \mathrm{H})=7.33 \mathrm{~Hz}, 2 \mathrm{H}\right.$; Ar-H $), 6.50\left(\mathrm{t},{ }^{3} J(\mathrm{H}, \mathrm{H})=\right.$ $7.33 \mathrm{~Hz}, 1 \mathrm{H} ; \mathrm{Ar}-\mathrm{H}), 3.22$ (br, $4 \mathrm{H} ; \mathrm{CH}_{2}$ ), 1.12 (br, $\left.36 \mathrm{H} ; \mathrm{CH}_{3}\right),-5.05$ (br, $\left.2 \mathrm{H} ; \mathrm{Ru}-\mathrm{H}_{2}\right),-7.012$ (br, 2H; Ru- $\left.\mathrm{H}_{2}\right),-11.8 \mathrm{ppm}\left(\mathrm{t},{ }^{2} J(\mathrm{H}, \mathrm{H})=17.7 \mathrm{~Hz}\right.$, $1 \mathrm{H}$; Ru-H); ${ }^{31} \mathrm{P}$ NMR (122 MHz, $\left.\left[\mathrm{D}_{8}\right] \mathrm{THF},-80^{\circ} \mathrm{C}\right): \delta=109.05 \mathrm{ppm}(\mathrm{s})$; IR (KBr): $\tilde{v}=2156$ (w; Ru-H), 2084 (w; Ru-H), 2013 cm$^{-1}$ (w; Ru-H); elemental analysis calcd (\%) for $\mathrm{C}_{24} \mathrm{H}_{48} \mathrm{P}_{2} \mathrm{Ru}$ (499.7): $\mathrm{C} 57.69, \mathrm{H} 9.68, \mathrm{P}$ 12.40, Ru 20.23; found: C 56.45, H 9.44, P 12.19 (sum 78.08\% found); found atom ratio number by $\mathrm{CHN}: \mathrm{C}_{24} \mathrm{H}_{47.8} \mathrm{P}_{2.0} \mathrm{Ru}_{1.1}$; detection of [Ru$\left.(\mathrm{dtbpmb})\left(\mathrm{H}_{2}\right) \mathrm{H}\right] \mathbf{1 3}$ in solution: ${ }^{1} \mathrm{H}$ NMR $\left(300 \mathrm{MHz},\left[\mathrm{D}_{8}\right] \mathrm{THF},-80^{\circ} \mathrm{C}\right)$ : $\delta=6.94\left(\mathrm{~d},{ }^{3} J(\mathrm{H}, \mathrm{H})=7.33 \mathrm{~Hz}, 2 \mathrm{H} ; \mathrm{Ar}-\mathrm{H}\right), 6.62\left(\mathrm{t},{ }^{3} J(\mathrm{H}, \mathrm{H})=7.33 \mathrm{~Hz}\right.$, $1 \mathrm{H}$; Ar-H), 3.42 (br, 4H; $\left.\mathrm{CH}_{2}\right), 1.12\left(\mathrm{br}, 36 \mathrm{H} ; \mathrm{CH}_{3}\right),-3.67$ (br, $2 \mathrm{H} ; \mathrm{Ru}-$ $\left.\mathrm{H}_{2}\right),-35.19 \mathrm{ppm}$ (br, $\left.1 \mathrm{H} ; \mathrm{Ru}-\mathrm{H}\right) ;{ }^{31} \mathrm{P}$ NMR $\left(122 \mathrm{MHz},\left[\mathrm{D}_{8}\right] \mathrm{THF}\right.$, $\left.-80^{\circ} \mathrm{C}\right): \delta=104.30 \mathrm{ppm}(\mathrm{s})$.

[Ru(dtbpmp) $\left.\mathbf{H}_{2}\left(\mathbf{H}_{2}\right)\right]$ (6): A Büchi glass autoclave, equipped with a stirring bar, was filled with $\left[\mathrm{Ru}(\mathrm{cod})(\text { metallyl })_{2}\right](\mathbf{1 1})(281 \mathrm{mg}, 0.88 \mathrm{mmol}$;
1 equiv), dtbpmp (17) (364 mg, $0.92 \mathrm{mmol} ; 1.05$ equiv) and degassed $n$ pentane $(12 \mathrm{~mL})$. The autoclave was flushed with 2 bar $\mathrm{H}_{2}$ gas (or $\mathrm{D}_{2}$ gas) at room temperature, then the temperature was increased to $55^{\circ} \mathrm{C}$ (oil bath), and the $\mathrm{H}_{2}$ pressure was stabilised at 7 bar. The reaction was stirred for $18 \mathrm{~h}$, cooled to room temperature and the $\mathrm{H}_{2}$ pressure was decreased to 1 bar. The red solution was filtered through a cannula under an $\mathrm{H}_{2}$ stream and the remaining solid was washed under an $\mathrm{H}_{2}$ stream with $n$-pentane to give a yellow-brown solid, which was primarily stored under 1 bar hydrogen in the autoclave. The product was transferred into a dry Schlenk tube using a glove box and further dried under an $\mathrm{H}_{2}$ stream. Finally it was stored under 1 bar hydrogen in an additionally sealed (parafilm) Schlenk tube at $-20{ }^{\circ} \mathrm{C}(323 \mathrm{mg}, 74 \%) .{ }^{1} \mathrm{H}$ NMR $\left(300 \mathrm{MHz}, \mathrm{C}_{6} \mathrm{D}_{6}, 25^{\circ} \mathrm{C}\right): \delta=6.8\left(\mathrm{t}, 1 \mathrm{H},{ }^{3} \mathrm{~J}(\mathrm{H}, \mathrm{H})=7.7 \mathrm{~Hz}\right.$; pyridine- $\left.\mathrm{H} 4\right)$, $6.6(\mathrm{~d}, 2 \mathrm{H}$,

${ }^{3} J(\mathrm{H}, \mathrm{H})=7.9 \mathrm{~Hz}$; pyridine-H3,5), 3.1 (virtual t, $4 \mathrm{H},{ }^{2} J(\mathrm{H}, \mathrm{P})=3.2 \mathrm{~Hz}$; $\left.\mathrm{CH}_{2} \mathrm{P}\right), 1.3$ (virtual t, $\left.36 \mathrm{H},{ }^{3} J(\mathrm{H}, \mathrm{P})=6.1 \mathrm{~Hz} ; \mathrm{PC}\left(\mathrm{CH}_{3}\right)_{3}\right),-7.3 \mathrm{ppm}(\mathrm{t}$, $\left.4 \mathrm{H},{ }^{2} J(\mathrm{H}, \mathrm{H})=13,2 \mathrm{~Hz} ; \mathrm{Ru}-H, \mathrm{Ru}-H_{2}\right) ;{ }^{13} \mathrm{C} \mathrm{NMR}\left(75 \mathrm{MHz}, \mathrm{C}_{6} \mathrm{D}_{6}\right.$, $25^{\circ} \mathrm{C}$ ): $\delta=164$ (d virtual t, ${ }^{2} J(\mathrm{C}, \mathrm{P})=4.8 \mathrm{~Hz}$; pyridine-C2,6), 133 (s, pyridine-C4), 118 (m, pyridine-C3,5), 41 (d virtualt, ${ }^{1} J(\mathrm{C}, \mathrm{P})=4.9 \mathrm{~Hz}$; $\left.\mathrm{CH}_{2} \mathrm{P}\right), 34$ (d virtualt, $\left.{ }^{1} J(\mathrm{C}, \mathrm{P})=6.7 \mathrm{~Hz} ; \mathrm{PC}\left(\mathrm{CH}_{3}\right)_{3}\right), 30 \mathrm{ppm}$ (vt, $\left.{ }^{2} J(\mathrm{C}, \mathrm{P})=3.4 \mathrm{~Hz} ; \mathrm{PC}\left(\mathrm{CH}_{3}\right)_{3}\right) ;{ }^{31} \mathrm{P}$ NMR $\left(122 \mathrm{MHz}, \mathrm{C}_{6} \mathrm{D}_{6}, 25^{\circ} \mathrm{C}\right): \delta=$ 109.5 ppm (s); IR (KBr) $\tilde{v}=3074\left(\mathrm{w}, v ; \mathrm{CH}_{\mathrm{ar}}\right), 3041$ (w, $\left.v ; \mathrm{CH}_{\mathrm{ar}}\right), 3018$ $\left(\mathrm{w}, v ; \mathrm{CH}_{\mathrm{ar}}\right), 2983\left(\mathrm{w}, v ; \mathrm{CH}_{2}\right), 2940\left(\mathrm{~s}, v ; \mathrm{CH}_{2}\right), 2893\left(\mathrm{~s}, v ; \mathrm{CH}_{2}\right), 2862(\mathrm{~s}$, $\left.v ; \mathrm{CH}_{2}\right), 2095\left(\mathrm{w}, v ; \mathrm{Ru}-\mathrm{H}_{2}\right), 1990-1700(\mathrm{~m}, v ; \mathrm{Ru}-\mathrm{H}), 1592(\mathrm{~m}, v ; \mathrm{C}=\mathrm{N})$, $1562(\mathrm{~m}, v ; \mathrm{C}=\mathrm{C}), 1459\left(\mathrm{~s}, \delta ; \mathrm{CH}_{2}\right), 1382(\mathrm{~s}, \delta ; t \mathrm{Bu}), 1363(\mathrm{~s}, \delta ; t \mathrm{Bu}), 1180$ $(\mathrm{m}, v$; $-\mathrm{P}), 833 \mathrm{~cm}^{-1}\left(\mathrm{~s}, \delta ; \mathrm{CH}_{\mathrm{ar}}\right)$; detection of $T_{1}(\mathrm{~min})$ of the hydride signal: $\left(400 \mathrm{MHz},\left[\mathrm{D}_{8}\right]\right.$ toluene, $\left.25^{\circ} \mathrm{C}\right): \delta=-7.3 \mathrm{ppm}\left(\mathrm{t}, 4 \mathrm{H},{ }^{2} J(\mathrm{H}, \mathrm{P})=\right.$ $13.2 \mathrm{~Hz}) ; T_{1}(\mathrm{~min})=77 \mathrm{~ms}\left(\theta_{\min }=228 \mathrm{~K}\right), r(\mathrm{H}-\mathrm{H})=111 \mathrm{pm}$; elemental analysis calcd (\%) for $\mathrm{C}_{23} \mathrm{H}_{47} \mathrm{NP}_{2} \mathrm{Ru}(500.7)$ : C 55.18, H 9.46, N 2.80, P 12.37, Ru 20.19; found: C 54.11, H 9.22, N 2.64, P 11.81, Ru 19.82 (sum: $97.6 \%$ found); found atom ratio number by $\mathrm{CHN}: \mathrm{C}_{23} \mathrm{H}_{46.7} \mathrm{~N}_{1.0} \mathrm{P}_{2.0} \mathrm{Ru}_{1.0}$.

$\left[D_{x}\right]$-[Ru(dtbpmp) $\left.\mathbf{H}_{2}\left(\mathbf{H}_{2}\right)\right]\left[\mathbf{D}_{x}\right]-6$ : Prepared as $\mathbf{6}$ by the use of deuterium gas to give a yellow-brown solid $(118 \mathrm{mg}, 54 \%)$. ${ }^{1} \mathrm{H}$ NMR $(300 \mathrm{MHz}$, $\left.\mathrm{C}_{6} \mathrm{D}_{6}, 25^{\circ} \mathrm{C}\right): \delta=6.8\left(\mathrm{t}, 0.1 \mathrm{H},{ }^{3} \mathrm{~J}(\mathrm{H}, \mathrm{H})=7.7 \mathrm{~Hz}\right.$; pyridine- $\left.\mathrm{H} 4\right), 6.6(\mathrm{~d}$, $2 \mathrm{H}, \quad{ }^{3} J(\mathrm{H}, \mathrm{H})=7.9 \mathrm{~Hz} ; \quad$ pyridine-H3,5), $3.1 \quad(\mathrm{vt}, \quad 3 \mathrm{H}$, $\left.{ }^{2} J(\mathrm{P}, \mathrm{H})=3.2 \mathrm{~Hz} ; \mathrm{CH}_{2} \mathrm{P}\right), 1.3\left(\mathrm{vt}, 36 \mathrm{H},{ }^{3} J(\mathrm{P}, \mathrm{H})=6.1 \mathrm{~Hz} ; \mathrm{PC}\left(\mathrm{CH}_{3}\right)_{3}\right)$, $-7.3 \mathrm{ppm}\left(\mathrm{t}, \quad 4 \mathrm{H},{ }^{3} J(\mathrm{H}, \mathrm{H})=13.2 \mathrm{~Hz} ; \mathrm{Ru}-\mathrm{H}, \mathrm{Ru}-\mathrm{H}_{2}\right) ;{ }^{2} \mathrm{H}$ NMR $\left(600 \mathrm{MHz}, \mathrm{C}_{6} \mathrm{D}_{6}, 25^{\circ} \mathrm{C}\right): \delta=6.8$ (s, weak; pyridine-D4), 6.6 (s, weak; pyridine-D3,5), 3.1 (s; $\left.\mathrm{CD}_{2} \mathrm{P}\right), 1.3$ (s; $\left.\mathrm{PC}\left(\mathrm{CD}_{3}\right)_{3}\right),-7.3$ ppm (s; Ru- $D, \mathrm{Ru}-$ $\left.D_{2}\right) ;{ }^{13} \mathrm{C}$ NMR $\left(75 \mathrm{MHz}, \mathrm{C}_{6} \mathrm{D}_{6}, 25^{\circ} \mathrm{C}\right.$ ): $\delta=133$ (s; pyridine-C4), 164 (pyridine-C2,6), $118\left(\mathrm{~m}\right.$; pyridine-C3,5), $41\left(\mathrm{PC}\left(\mathrm{CH}_{3}\right)_{3}\right), 33\left(\mathrm{CH}_{2} \mathrm{P}\right), 30 \mathrm{ppm}$ $\left(\mathrm{PC}\left(\mathrm{CH}_{3}\right)_{3}\right) ;{ }^{31} \mathrm{P}$ NMR $\left(122 \mathrm{MHz}, \mathrm{C}_{6} \mathrm{D}_{6}, 25^{\circ} \mathrm{C}\right): \delta=109.1 \mathrm{ppm}(\mathrm{s})$; IR $(\mathrm{KBr}): \tilde{v}=3012\left(\mathrm{w}, v ; \mathrm{CH}_{\mathrm{ar}}\right), 2983\left(\mathrm{~s}, v ; \mathrm{CH}_{2}\right), 2946\left(\mathrm{~s}, v ; \mathrm{CH}_{2}\right), 2900(\mathrm{~s}$, $\left.v ; \mathrm{CH}_{2}\right), 2863\left(\mathrm{~s}, v ; \mathrm{CH}_{2}\right), 2247\left(\mathrm{w}, v ; \mathrm{CD}_{\mathrm{ar}}\right), 2199\left(\mathrm{w}, v ; \mathrm{CD}_{\mathrm{ar}}\right), 2151(\mathrm{w}, v$; $\mathrm{CD}_{\mathrm{ar}}$ ), $2094\left(\mathrm{w}, v ; \mathrm{Ru}-\mathrm{H}_{2}\right), 2000-1700(\mathrm{~m}, v ; \mathrm{Ru}-\mathrm{H}), 1582(\mathrm{~m}, v ; \mathrm{C}=\mathrm{N})$, $1546(\mathrm{~m}, v ; \mathrm{C}=\mathrm{C}), 1458\left(\mathrm{~s}, \delta ; \mathrm{CH}_{2}\right), 1362(\mathrm{~s}, \delta ; t \mathrm{Bu}), 707 \mathrm{~cm}^{-1}(\mathrm{~s}, \delta ;$ $\mathrm{CH}_{\mathrm{ar}}$ ).

Reaction of $\left[\mathrm{Ru}(\mathrm{dtbpmp}) \mathrm{H}_{2}\left(\mathrm{H}_{2}\right)\right]$ (6) with $\mathrm{C}_{6} \mathrm{D}_{6}$ to form highly deuterated $\left[\mathbf{D}_{x}\right]$-6: A Young Teflon capped NMR tube was filled with 6 (20 mg, $39.9 \mu \mathrm{mol})$ and $\mathrm{C}_{6} \mathrm{D}_{6}(0.5 \mathrm{~mL})$ was added. The red solution was stirred at $50{ }^{\circ} \mathrm{C}$ for $2 \mathrm{~d}$, cooled to RT, and the ${ }^{1} \mathrm{H}$ NMR and ${ }^{31} \mathrm{P}$ NMR spectra were measured manually locked on $\mathrm{C}_{6} \mathrm{D}_{6}$. Deuteration degree: $>90 \% ;{ }^{1} \mathrm{H}$ NMR (300 MHz, $\left.\mathrm{C}_{6} \mathrm{D}_{6}, 25^{\circ} \mathrm{C}\right): \delta=6.8$ (residue; pyridine-H4), 6.6 (residue; pyridine-H3,5), 3.1 (residue; $\mathrm{CH}_{2} \mathrm{P}$ ), 1.3 (residue; $\mathrm{PC}\left(\mathrm{CH}_{3}\right)_{3}$ ), $-7.3 \mathrm{ppm}$ (residue; Ru- $H$, Ru- $\left.\mathrm{H}_{2}\right) ;{ }^{2} \mathrm{H}$ NMR $\left(600 \mathrm{MHz}, \mathrm{C}_{6} \mathrm{D}_{6}, 25^{\circ} \mathrm{C}\right): \delta$ $=6.8\left(\mathrm{~s}\right.$; pyridine-D4), $6.6\left(\mathrm{~s}\right.$; pyridine-D3,5), $3.1\left(\mathrm{~s} ; \mathrm{C} D_{2} \mathrm{P}\right), 1.3(\mathrm{~s} ; \mathrm{PC}-$ $\left.\left(\mathrm{C} D_{3}\right)_{3}\right),-7.3 \mathrm{ppm}\left(\mathrm{s} ; \mathrm{Ru}-D, \mathrm{Ru}-D_{2}\right) ;{ }^{31} \mathrm{P}$ NMR $\left(122 \mathrm{MHz}, \mathrm{C}_{6} \mathrm{D}_{6}, 25^{\circ} \mathrm{C}\right)$ : $\delta=108.1 \mathrm{ppm}$ (s).

Reaction of $\left[\mathrm{Ru}(\mathrm{dtbpmp}) \mathrm{H}_{2}\left(\mathrm{H}_{2}\right)\right]$ (6) with nitrogen gas to form [Ru(dtbpmp) $\mathbf{H}_{2}\left(\mathbf{N}_{2}\right)$ ] (18): A Young Teflon-capped NMR tube containing a dark red solution of $\mathbf{6}(20 \mathrm{mg}, 39.9 \mu \mathrm{mol})$ in $\left[\mathrm{D}_{8}\right]$ toluene $(0.6 \mathrm{~mL})$ was slowly bubbled with $\mathrm{N}_{2}$ at room temperature. ${ }^{1} \mathrm{H}$ and ${ }^{31} \mathrm{P}$ NMR spectra were measured after $90 \mathrm{~min}$ (red solution) and $20 \mathrm{~h}$ (black mixture). The black mixture was then bubbled with $\mathrm{H}_{2}$ for $1 \mathrm{~d}$ and ${ }^{1} \mathrm{H}$ and ${ }^{31} \mathrm{P}$ NMR spectra were recorded again. Conversion: $66 \%\left({ }^{31} \mathrm{P}\right.$ NMR after $\left.90 \mathrm{~min}\right)$; ${ }^{1} \mathrm{H}$ NMR $\left(300 \mathrm{MHz},\left[\mathrm{D}_{8}\right]\right.$ toluene, $\left.25^{\circ} \mathrm{C}\right): \delta=-4.6\left(\mathrm{t},{ }^{2} J(\mathrm{H}, \mathrm{P})=\right.$ $16.81 \mathrm{~Hz}),-12.8 \mathrm{ppm}$ (weak, broad); ${ }^{31} \mathrm{P}$ NMR $\left(122 \mathrm{MHz},\left[\mathrm{D}_{8}\right]\right.$ toluene, 
$\left.25^{\circ} \mathrm{C}\right): \delta=99.6 \mathrm{ppm}$ (brs). For further tabulated values see Supporting Information

\section{Acknowledgements}

Thanks are due to technical assistance of Reinhard Ettl, Conny Wirtz, and Bernd Waßmuth in the analytical departments of the MPI with NMR and IR experiments. Financial support of the Max-Planck-Society, the Fonds der Chemischen Industrie and the programme for Deutsch-Israelische Partnerschaft (DIP) is gratefully acknowledged.

[1] G. J. Kubas, R. R. Ryan, B. I. Swanson, P. J. Vergamini, H. J. Wasserman, J. Am. Chem. Soc. 1984, 106, 451-452.

[2] P. J. Jessop, R. H. Morris, Coord. Chem. Rev. 1992, 121, 155-284.

[3] a) G. J. Kubas, Acc. Chem. Res. 1988, 21, 120-128; b) G. J. Kubas, Metal Dihydrogen and $\sigma$-Bond Complexes, Kluwer Academic/ Plenum Press, New York, 2001.

[4] G. J. Kubas, J. Organomet. Chem. 2001, 635, 37-68.

[5] a) A. M. Kjoshi, K. S. MacFarlane, B. R. James, J. Organomet. Chem. 1995, 488, 161-167; b) G. Jia, W. S. Ng, C. P. Lau, Organometallics 1998, 17, 4538-4540.

[6] A. Dedieu, Transition Metal Hydrides, 1990, VCH, Weinheim.

[7] M. Y. Darensburg, E. J. Lyon, J. J. Smee, Coord. Chem. Rev. 2000, 206-207, 533-561.

[8] D. M. Heinekey, W. J. Oldham Jr., Chem. Rev. 1993, 93, 913-926.

[9] G. J. Kubas, C. J. Burns, J. Eckert, S. Johnson, A. C. Larson, P. J. Vergamini, C. J. Unkefer, G. R. K. Khalsa, S. A. Jackson, O. Eisenstein, J. Am. Chem. Soc. 1993, 115, 569-581.

[10] K. Almeida Leñero, M. Kranenburg, Y. Guari, P. C. J. Kamer, P. W. N. M. van Leeuwen, S. Sabo-Etienne, B. Chaudret, Inorg. Chem. 2003, 42, 2859-2866.

[11] Preliminary results of this study have been communicated in part in S. Busch, W. Leitner, Chem. Commun. 1999, 2305-2306.

[12] a) B. Chaudret, R. Poilblanc, Organometallics 1985, 4, 1722-1726; b) T. Arliguie, B. Chaudret, R. H. Morris, A. Sella, Inorg. Chem. 1988, 27, 598-599; c) A. F. Borowski, B. Donnadieu, J.-C. Daran, S. Sabo-Etienne, B. Chaudret, Chem. Commun. 2000, 543-544; d) M. Grellier, L. Vendier, B. Chaudret, A. Albinati, S. Rizzato, S. Mason, S. Sabo-Etienne, J. Am. Chem. Soc. 2005, 127, 17592-17593.

[13] A. F. Borowski, S. Sabo-Etienne, M. L. Christ, B. Donnadieu, B. Chaudret, Organometallics 1996, 15, 1427-1434.

[14] a) B. Chaudret, G. Chung, O. Eisenstein, S. A. Jackson, F. J. Lahoz, J. A. Lopez, J. Am. Chem. Soc. 1991, 113, 2314-2316; b) G. Chung, T. Arliguie, B. Chaudret, New J. Chem. 1992, 16, 369-374; c) M. L. Christ, S. Sabo-Etienne, B. Chaudret, Organometallics 1994, 13, 3800-3804.

[15] Y. Guari, S. Sabo-Etienne, B. Chaudret, J. Am. Chem. Soc. 1998, $120,4228-4229$.

[16] R. P. Beatty, R. A. Paciello (Du Pont), WO 96/23802, priority date 08.08.1996.

[17] F. Delpech, S. Sabo-Etienne, B. Donnadieu, B. Chaudret, Organometallics 1998, 17, 4926-4928.

[18] For studies of stability of Chaudret's complex under catalytic conditions see: a) S. Busch, W. Leitner, Adv. Synth. Catal. 2001, 343, 192-
195; b) Y. Guari, A. Castellanos, S. Sabo-Etienne, B. Chaudret, $J$. Mol. Catal. A Chem. 2004, 212, 77-82.

[19] T. R. Balderrain, R. H. Grubbs, Organometallics 1997, 16, $4001-$ 4003.

[20] D. Giunta, M. Hölscher, C. W. Lehmann, R. Mynott, C. Wirtz, W. Leitner, Adv. Synth. Catal. 2003, 345, 1139-1145.

[21] P. Buskens, D. Giunta, W. Leitner, Inorg. Chim. Acta 2004, 357, 1969-1974.

[22] a) M. E. van der Boom, D. Milstein, Chem. Rev. 2003, 103, 17591792; b) M. E. van der Boom, L. Hassner, Y. Ben-David, D. Milstein, Organometallics 1999, 18, 3873-3884; c) M. E. van der Boom, M. A. Iron, O. Atasoylu, L. J. W. Shimon, H. Rozenberg, Y. BenDavid, L. Konstantinovski, J. M. L. Martin, D. Milstein, Inorg. Chim. Acta 2004, 357, 1854-1864.

[23] a) D. G. Gusev, M. Madott, F. M. Dolgushin, K. A. Lyssenko, M. Y. Antipin, Organometallics 2000, 19, 1734-1739; b) D. G. Gusev, F. M Dolgushin, M. Y. Antipin, Organometallics 2000, 19, 3429-3434; c) D. G. Gusev, T. Maxwell, F. M. Dolgushin, K. A. Lyssenko, A. J. Lough, Organometallics 2002, 21, 1095-1100; d) E. J. Farrington, E. M. Viviente, B. S. Williams, G. van Koten, J. M. Brown, Chem. Commun. 2002, 308-309; e) D. Hermann, M. Gandelman, H. Rozenberg, L. J. W. Shimon, D. Milstein, Organometallics 2002, 21, $812-818$; f) Q. Major, A. J. Lough, D. G. Gusev, Organometallics 2005, 24, 2492-2501.

[24] C. Six, B. Gabor, H. Gorls, R. Mynott, P. Philipps, W. Leitner, Organometallics 1999, 18, 3316-3326.

[25] L. A. Woodward, Introduction to the Theory of Molecular Vibrations and Vibrational Spectroscopy, 1972, Oxford University Press, London, p. 207-214.

[26] a) R. H. Crabtree, Acc. Chem. Res. 1990, 23, 95-101; b) W. Yao, J. W. Faller, R. H. Crabtree, Inorg. Chim. Acta 1997, 259, 71-76.

[27] For details see Supporting Information. CCDC-612003 contains the supplementary crystallographic data for this structure. These data can be obtained free of charge from the Cambridge Crystallographic Data Centre via www.ccdc.cam.ac.uk/data_request/cif.

[28] a) B. Chaudret, J. Devillers, R. Poilblanc, Organometallics 1985, 4, 1727-1732; b) K. Abdur-Rashid, D. G. Gusev, A. J. Lough, R. H. Morris, Organometallics 2000, 19, 1652-1660.

[29] D. Amoros, A. Jabri, G. P. A. Yap, D. G. Gusev, E. N. dos Santos, D. E. Fogg, Organometallics 2004, 23, 4047-4054 and references therein.

[30] a) P. Hofmann, C. Meier, U. Englert, M. U. Schmidt, Chem. Ber. 1992, 125, 353; b) W. Leitner, M. Bühl, R. Fornika, C. Six, W. Baumann, E. Dinjus, M. Kessler, C. Krüger, A. Rufinska, Organometallics 1999, 18, 1196-1206.

[31] C. J. Moulton, B. L. Shaw, J. Chem. Soc. Dalton Trans. 1976, 10201024.

[32] a) J. Zhang, G. Leitus, Y. Ben-David, D. Milstein, J. Am. Chem. Soc 2005, 127, 10840-10841; b) J. Zhang, G. Leitus, Y. Ben-David, D Milstein, Angew. Chem. 2006, 118, 1131-1133; Angew. Chem. Int. Ed. 2006, 45, 1113-1115.

[33] D. D. Perrin, W. L. F. Armarego, Purification of Laboratory Chemicals, Pergamon Press, London.

[34] M. Kawatsura, J. F. Hartwig, Organometallics 2001, 20, 1960-1964.

Received: June 23, 2006 Published online: November 20, 2006 